\title{
Iwabradyna - lek dla współczesnego pacjenta z niewydolnością serca
}

\author{
Ivabradine - a drug for the modern patient with heart failure
}

\author{
Filip M. Szymański
}

I Katedra i Klinika Kardiologii Warszawskiego Uniwersytetu Medycznego

\section{Streszczenie}

Iwabradyna jest unikatowym, nowoczesnym lekiem, którego mechanizm działania polega na blokowaniu prądu $\mathrm{I}_{\mathrm{f}} \mathrm{W}$ węźle zatokowo-przedsionkowym. Przekłada się to na zmniejszenie częstości rytmu serca - parametru związanego z niekorzystnym rokowaniem u pacjentów z niewydolnością serca (HF). Współcześnie jest to inna grupa chorych niż spotykana w praktyce klinicznej jeszcze kilka lat temu. Ze względu na inną strukturę demograficzną i inne potrzeby zdrowotne metody leczenia farmakologicznego również muszą ulegać ciągłej modyfikacji. Iwabradyna to lek odpowiadający na potrzeby współczesnego pacjenta z HF - zapewniający nie tylko ograniczenie śmiertelności, ale także wpływający korzystnie na takie czynniki, jak ryzyko powtórnych hospitalizacji, parametry hemodynamiczne, wydolność wysiłkowa i jakość życia. Słowa kluczowe: iwabradyna, niewydolność serca, częstość rytmu serca

Folia Cardiologica 2015; 10, 5: 348-353

\section{Wprowadzenie}

Choć w ostatnich latach poczyniono znaczne postępy w zakresie diagnozowania i leczenia pacjentów z chorobami układu krążenia, to wciąż istnieją schorzenia, z którymi lekarze nie są w stanie sobie dostatecznie dobrze radzić. Jednym z nich jest niewydolność serca - konsekwencja i zejściowa forma takich chorób, jak choroba wieńcowa, nadciśnienie tętnicze czy tachyarytmie. Niewydolność serca łączy się z niekorzystnym rokowaniem, nieuchronnie prowadząc do inwalidztwa i zgonu. Jest także jedną z chorób układu krążenia stanowiących ogromny problem dla systemów ochrony zdrowia na całym świecie. Szacuje się, że w najbliższych latach częstość występowania niewydolności serca będzie wzrastać, głównie ze względu na starzenie się społeczeństwa i zwiększenie przeżywalności po incydentach wieńcowych [1]. Potwierdzono to również w dostępnych badaniach epidemiologicznych z ostatnich lat.

Łączna liczba osób na świecie ze zdiagnozowaną niewydolnością serca wynosi około $23 \mathrm{mln}$, co w przeliczeniu od- powiadałoby $60 \%$ mieszkańców Polski. Przekłada się to na 1-2\% populacji ogólnej, która jest dotknięta niewydolnością serca. Co więcej, co roku tylko w Stanach Zjednoczonych odnotowuje się 0,5 mln nowych zachorowań [2, 3]. Ryzyko zgonu spowodowanego niewydolnością serca, w ciągu 5 lat od rozpoznania choroby, jeszcze przed 20-30 laty wynosiło $60 \%$, jednak w polskich badaniach epidemiologicznych w 2005 roku wykazano, że się ono zmniejszyło o około 50\% [4, 5]. Po 2005 roku epidemiologia niewydolności serca zaczęła się zmieniać - dzięki rozwojowi farmakoterapii wydłużyła się średnia długość życia w populacji ogólnej oraz wśród pacjentów z niewydolnością serca w Polsce. Podobne trendy rysują się w większości rozwiniętych krajów europejskich, w tym w Wielkiej Brytanii, Czechach, Szkocji czy Szwecji [6-9]. Korzystna redukcja liczby zgonów z powodu niewydolności serca jest w dużej mierze wywołana obniżeniem ryzyka nagłego zgonu sercowego - głównej konsekwencji działania $\beta$-adrenolityków, inhibitorów konwertazy angiotensyny, antagonistów aldosteronu oraz kardiowerterów-defibrylatorów wszczepianych pacjentom.

Adres do korespondencji: dr hab. n. med. Filip M. Szymański, I Katedra i Klinika Kardiologii, Warszawski Uniwersytet Medyczny, ul. Banacha 1a, 02-097 Warszawa, tel.: 2259919 58, faks 22599 19 57, e-mail: filip.szymanski@wum.edu.pl 
Wszystko to sprawiło, że nie tylko wzrosła bezwzględna liczba zgonów spowodowanych niewydolnością serca, ale także wydłużyło się życie z chorobą. Tym istotniejsze wydaje się poszukiwanie nowych metod leczenia niewydolności serca oraz poprawy funkcjonowania i jakości życia pacjentów z tym schorzeniem.

\section{Na co należy obecnie zwracać uwagę u pacjenta z niewydolnością serca?}

Optymalizacja farmakoterapii stanowi obecnie najważniejszą metodę poprawy rokowania pacjentów z niewydolnością serca. Jednym z celów farmakoterapii, często - niestety - niedostatecznie docenianym w tej grupie chorych, jest zmniejszenie częstości rytmu serca. Przykładów poprawy rokowania pacjentów z niewydolnością serca wynikających z redukcji częstości rytmu serca dostarczają wyniki wielu ogromnych badań. W jednym z nich analizowano rokowanie 1947 pacjentów z hospitalizowanych z powodu niewydolności serca, z frakcją wyrzutową (EF, ejection fraction) lewej komory nie większą niż 40\%, u których nie występowało migotanie czy trzepotanie przedsionków ani nie byli zależni od stymulatora serca [10]. Średni okres obserwacji wynosił 9,9 miesiąca. Wykazano, że wyjściowo pacjenci z większą częstością rytmu serca byli młodsi, mieli niższą EF, większe nasilenie objawów w skali New York Heart Association (NYHA) oraz wyższe stężenia peptydów natriuretycznych. Dowiedziono, że w grupie pacjentów z częstością rytmu serca większą lub równą 70/min zwiększenie częstości rytmu serca łączyło się z gorszym rokowaniem. Każdy wzrost tętna o 5/min tydzień po wypisaniu ze szpitala wiązał się ze wzrostem całkowitego ryzyka zgonu o 13\% (współczynnik ryzyka [HR, hazard ratio] 1,13; 95-proc. przedział ufności [Cl, confidence interval] 1,05-1,22; $p=0,002)$. Podobnie wzrost częstości rytmu serca o 5/min 4 tygodnie po wypisaniu łączył się ze wzrostem ryzyka o 12\% (HR 1,12; 95\% Cl 1,05-1,19; $p=0,001$ ).

W innym badaniu porównywano, jak częstość rytmu serca mierzona przy wypisaniu ze szpitala koreluje z ryzykiem zgonu [11]. Do badania włączono 9097 pacjentów, których podzielono ze względu na częstość rytmu serca na 5 grup: 1) 40-60/min, 2) 61-70/min, 3) $71-80 / \mathrm{min}, 4)$ 81-90/min i 5) > 90/min. Wykazano, że w grupach z wyższą częstością rytmu serca odnotowuje się podwyższone ryzyko hospitalizacji z powodu niewydolności serca lub chorób układu krążenia, wyższe całkowite ryzyko zgonu oraz ryzyko zgonu sercowo-naczyniowego w obserwacji 30-dniowej. Natomiast w stosunku do rocznego rokowania zaobserwowano między innymi, że roczne całkowite ryzyko zgonu jest o 41\% wyższe (iloraz szans [OR, odds ratio] 1,41; 95\% Cl 1,16-1,72; p < 0,001), a ryzyko zgonu z przyczyn sercowo-naczyniowych - o 47\% wyższe (OR 1,47; 95\% Cl 1,12-1,92; $p=0,005)$ u pacjentów z częstością rytmu serca ponad 90/min niż u pacjentów, u których tętno wynosiło 40-60/min. Obserwowana zależność stała się przyczyną poszukiwania metod farmakoterapii ukierunkowanej na zmniejszenie częstości rytmu serca, które miałyby nie tylko dalej zredukować ryzyko zgonu pacjentów z niewydolnością serca, ale także poprawić ich wydolność i jakość życia. Leki $\beta$-adrenolityczne oraz antagoniści wapnia, mimo swojego wpływu na częstość rytmu serca, powodowały także inne działania hemodynamiczne oraz wpływały na zdolność skurczu mięśnia sercowego. Prace nad lekiem pozbawionym niekorzystnego wpływu na siłę skurczu (inotropowego), relaksację (luzitropowego) oraz przewodzenie (dromotropowego) w mięśniu sercowym trwały ponad 20 lat [12]. Substancją o takich właściwościach okazała się iwabradyna.

Mechanizm działania leku polega na blokowaniu prą$\mathrm{du} \mathrm{I}_{\mathrm{f}} \mathrm{w}$ węźle zatokowo-przedsionkowym. Prąd $\mathrm{I}_{\mathrm{f}}$ odgrywa kluczową rolę w generowaniu rozkurczowej depolaryzacji mięśnia sercowego. Kanały $f$ pierwotnie opisano w węźle zatokowo-przedsionkowym, ale ich ekspresję potwierdzono także w węźle przedsionkowo-komorowym i innych tkankach przewodzących. Iwabradyna łączy się z wysoką specyficznością z kanałami $f$ i blokuje otwarte kanały $f$ w sposób zależny od stężenia i woltażu. Co istotne, siła wiązania iwabradyny z kanałem jonowym zwiększa się wraz z częstością zmiany cyklu otwierania-zamykania kanału. Sprawia to, że lek silniej wiąże się ze swoim miejscem docelowym w komórkach, które często się depolaryzują - a więc u pacjentów z większą częstością rytmu serca [12], jednocześnie słabiej działając u chorych z wyjściowo wolniejszym rytmem serca, co powoduje minimalne ryzyko bradykardii, a przez to czyni lek niezwykle łatwym w inicjacjowaniu i kontynuacji terapii. Zastosowanie iwabradyny powoduje zmniejszenie częstości rytmu serca poprzez wydłużenie czasu depolaryzacji mięśnia sercowego, a jednocześnie nie wykazuje negatywnego wpływu na wspomniane wyżej funkcje mięśnia sercowego ani wartości ciśnienia tętniczego.

\section{Znaczenie kliniczne zmniejszenia częstości rytmu serca}

Jednym z najważniejszych badań, w którym dowiedziono, jak istotne jest zmniejszenie częstości rytmu serca u pacjentów z niewydolnością serca, a jednocześnie wykazano skuteczność iwabradyny, jest badanie SHIFT (Systolic Heart failure treatment with the $I_{f}$ inhibitor ivabradine Trial) [13]. Do tego dobrze znanego badania włączono pacjentów z objawową niewydolnością serca i EF mniejszą lub równą 35\% oraz rytmem zatokowym o częstości większej lub równej 70/min, którzy w roku poprzedzającym włączenie do badania przebyli hospitalizację z powodu niewydolności serca, a obecnie byli optymalnie leczeni (również $\beta$-adrenolitykiem, jeżeli był tolerowany). Pacjentów poddano randomizacji do grup przyjmującej iwabradynę w dawce maksymalnej 7,5 $\mathrm{mg} /$ dobę lub otrzymującej placebo. Pierwotny punkt końcowy stanowiły zgon z przyczyn sercowo-naczyniowych lub 
hospitalizacja z powodu niewydolności serca. Wykazano, że w całej badanej populacji stosowanie leku i związana z nim istotna redukcja częstości rytmu serca spowodowały 18-procentowe obniżenie ryzyka wystąpienia pierwotnego złożonego punktu końcowego (HR 0,82; 95\% Cl 0,75-0,90; $p<0,0001)$. Było to spowodowane dwoma czynnikami:

- 26-procentową redukcją ryzyka hospitalizacji z powodu niewydolności serca (HR 0,74; 95\% Cl 0,66-0,83; p < 0,0001);

- 26-procentową redukcją ryzyka zgonu z powodu niewydolności serca (HR 0,74; 95\% Cl 0,58-0,94; p = 0,014). Jeszcze korzystniejsze efekty działania leku potwierdzono w podgrupie uczestników tego samego badania, u których wyjściowo częstość rytmu serca wynosiła $\geq 75$ / min. Stwierdzono, że w tej grupie pacjentów iwabradyna powodowała [14]:

- 17-procentową redukcję całkowitego ryzyka zgonu (HR 0,83; 95\% Cl 0,72-0,96; $p=0,0109$ );

- 17-procentową redukcję ryzyka zgonu z przyczyn sercowo-naczyniowych (HR 0,83; 95\% Cl 0,71-0,97; $p=0,0166)$;

- 39-procentową redukcję ryzyka zgonu z powodu niewydolności serca (HR 0,61; 95\% Cl 0,46-0,81; $p<0,0006$ ) (ryc. 1);

- 30-procentową redukcję ryzyka hospitalizacji z powodu niewydolności serca (HR 0,70; 95\% Cl 0,61-0,80; $p<0,0001$ ).

W większości przypadków obniżenie ryzyka zgonu spowodowanego niewydolnością serca było efektem blokowania mechanizmu zgonu w przebiegu niewydolności

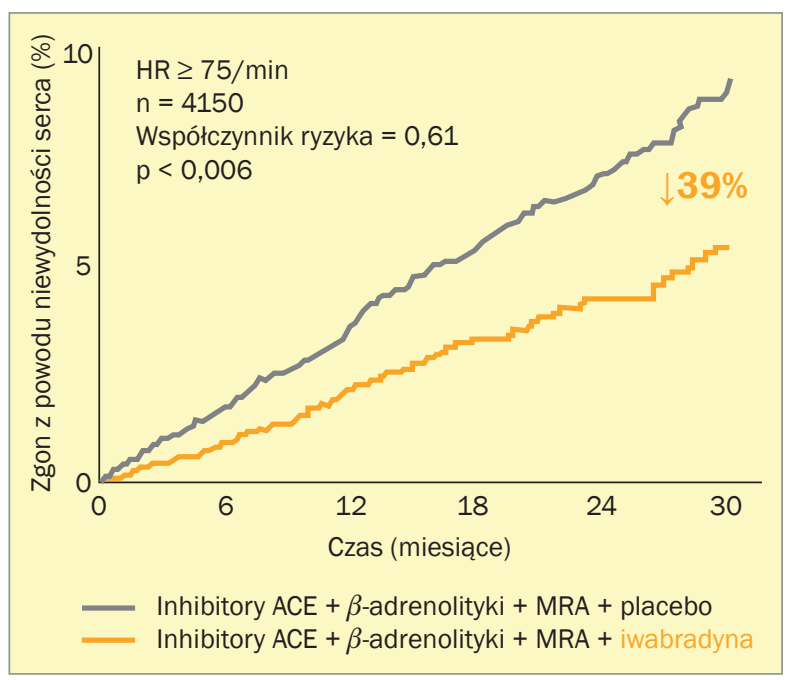

Rycina 1. Wpływ iwabradyny na obniżenie względnego ryzyka zgonu z powodu niewydolności serca w badaniu SHIFT (podgrupa z HR $\geq 75 /$ min) (opracowano na podstawie [14]); HR (heart rate) - częstość rytmu serca; ACE (angiotensin-converting enzyme) enzym konwertazy angiotensyny; MRA (mineral corticoid receptor antagonists) - antagoniści receptorów mineralokortykoidowych serca jako pompy, a nie nagłego zgonu sercowego, którego ryzyko minimalizują inne, stosowane obecnie, formy farmakoterapii.

Te korzystne wyniki potwierdzają zasadność stosowania iwabradyny u pacjentów z podwyższoną częstością rytmu serca, a w stosunku do samego leku przekonują, że iwabradyna dodana do optymalnej farmakoterapii poprawia rokowanie pacjentów z niewydolnością serca.

\section{Wpływ blokowania prądu If na ryzyko hospitalizacji}

Jak można zauważyć, jednym z punktów końcowych ocenianych w cytowanych wyżej badaniach było ryzyko hospitalizacji z powodu niewydolności serca. Choroba ta odpowiada za ponad milion hospitalizacji rocznie, zarówno w Stanach Zjednoczonych, jak i Europie. Choć rokowanie pacjentów z niewydolnością serca leczonych ambulatoryjnie uległo istotnej poprawie, to niestety odsetek śmiertelności wewnątrzszpitalnej oraz ponownych hospitalizacji nie zmniejszył się w ostatnich dwóch dekadach [15]. Dlatego ciągle istnieje potrzeba dalszej redukcji liczby i częstości hospitalizacji, zwłaszcza że korelują z gorszym rokowaniem w przyszłości oraz generują ogromne koszty socjoekonomiczne.

Obserwacje te potwierdzono w jednej z analiz badania CHARM (Candesartan in Heart failure: Assessment of Reduction in Mortality and morbidity) [16]. Oceniano w nim grupę 7572 pacjentów, wykazując, że 19\% z nich przebyło co najmniej jedną hospitalizację z powodu niewydolności serca w czasie 38 miesięcy obserwacji. Udowodniono także, że sama hospitalizacja ponad 3-krotnie zwiększa ryzyko zgonu pacjenta (HR 3,15; 95\% Cl 2,83-3,50; $p<0,001$ ), a ryzyko było tym wyższe, im dłużej trwały hospitalizacje i im większa była ich liczba. Co istotne, najwyższe ryzyko zgonu odnotowano w pierwszym miesiącu po hospitalizacji, co wskazuje na ogromne znaczenie optymalizacji leczenia niewydolności serca - w tym rozpoczęcia leczenia iwabradyną - już w momencie wypisania pacjenta ze szpitala, nawet jeżeli nie udało się jeszcze osiągnąć pożądanej dawki leku $\beta$-adrenolitycznego.

Korzyść z zastosowania iwabradyny w redukcji ryzyka kolejnych hospitalizacji z powodu niewydolności serca potwierdzono w jednej z analiz badania SHIFT [17]. Wykazano w niej, że w grupie 6505 pacjentów 1186 osób przebyło jedną hospitalizację, 472 - dwie hospitalizacje, a 218 co najmniej trzy. Zastosowanie iwabradyny łączyło się z obniżeniem o 25\% całkowitego ryzyka hospitalizacji (HR 0,75; 95\% Cl 0,65-0,87; $p=0,0002$ ) w czasie 22,9 miesiąca obserwacji, a także jeszcze istotniejszą redukcją ryzyka drugiej i kolejnych hospitalizacji (HR 0,66; 95\% Cl $0,55-0,79 ; p<0,001$ oraz HR 0,71; 95\% Cl 0,54-0,93; $p=0,012)$. 


\section{Wpływ blokowania prądu $I_{f}$ na funkcję mięśnia sercowego i jakość życia pacjentów}

Opisywany pożądany wpływ na ryzyko hospitalizacji spowodowanych niewydolnością serca oraz zgonu w mechanizmie niewydolności serca jako pompy są konsekwencją wywoływanych przez iwabradynę zmian hemodynamicznych i metabolicznych [18]. Wykazano, że stosowanie iwabradyny w modelach indukowanej niedokrwieniem niewydolności serca łączyło się redukcją końcowoskurczowego wymiaru lewej komory, bez wpływu na wymiar końcoworozkurczowy, co powodowało zachowanie rzutu serca poprzez zwiększenie objętości wyrzutowej. Histologicznie stosowanie iwabradyny powodowało także zmniejszenie gęstości włókien kolagenowych oraz zwiększenie gęstości naczyń włosowatych, co przekłada się na lepsze ukrwienie mięśnia sercowego, wskazując równocześnie na skuteczne zapobieganie długotrwałemu remodelingowi serca. Podobne działania iwabradyna wykazywała także po podaniu dożylnym u pacjentów z zaawansowaną niewydolnością serca [19]. W tej grupie chorych iwabradyna również powoduje redukcję częstości rytmu serca, zwiększenie objętości wyrzutowej oraz zachowanie rzutu serca, co wraz z wydłużeniem czasu rozkurczu prowadzi do poprawy perfuzji wieńcowej oraz zmniejszenia przeciążenia lewej komory [19, 20].

Poprawa właściwości hemodynamicznych związana z zastosowaniem iwabradyny wymiernie przekłada się także na kliniczne funkcjonowanie pacjentów. W badaniu CARVIVA dowiedziono, że zarówno stosowanie iwabradyny, jak i jej połączenia z karwedilolem skutkuje poprawą wyników testu 6-minutowego marszu (o 27\% w stosunku do wyjściowego dystansu) oraz możliwości wykonania anaerobowego wysiłku, a wyniki były korzystniejsze niż w przypadku podwojenia dawki $\beta$-adrenolityku [21]. W badaniu Sarullo i wsp. [22] wykazano także, że iwabradyna, poza istotną redukcją częstości rytmu serca, powoduje zwiększenie tolerancji wysiłku, zwiększa zużycie tlenu, a także wywołuje korzystną modulację neurohormonalną oraz poprawę wydolności fizycznej i jakości życia u pacjentów z niewydolnością serca.

Dwie ostatnie komponenty działania leku są szczególnie istotne w kontekście wyników współczesnych badań epidemiologicznych dotyczących polskich pacjentów. Jak to przedstawiono na rycinie 2 , pacjenci ci nie sa jeszcze dostatecznie dobrze leczeni, aby osiągnąć kontrolę objawów niewydolności serca [23] - większość wciąż odczuwa nasilone objawy choroby. Co więcej, również badania psychologiczne wskazują, że wykładniki samopoczucia chorych także nie są satysfakcjonujące, a pacjenci opierają swoje nadzieje w największym stopniu na prawidłowej opiece ze strony przedstawicieli służby zdrowia [24].

Również pod tym względem stosowanie iwabradyny okazało się korzystne [25]. W badaniu INTENSIFY (Practlcal

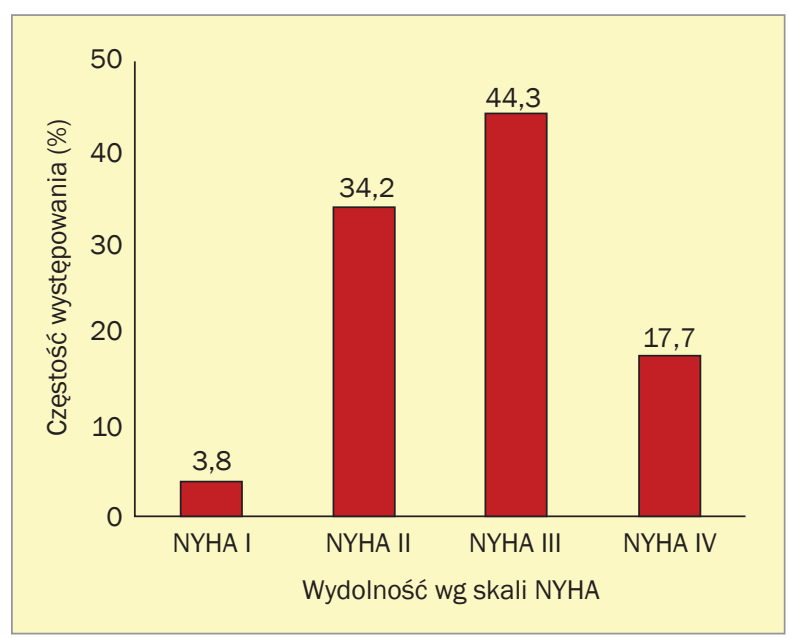

Rycina 2. Natężenie objawów niewydolności serca według klasyfikacji New York Heart Association (NYHA) wśród polskich pacjentów z tym schorzeniem (opracowano na podstawie [23])

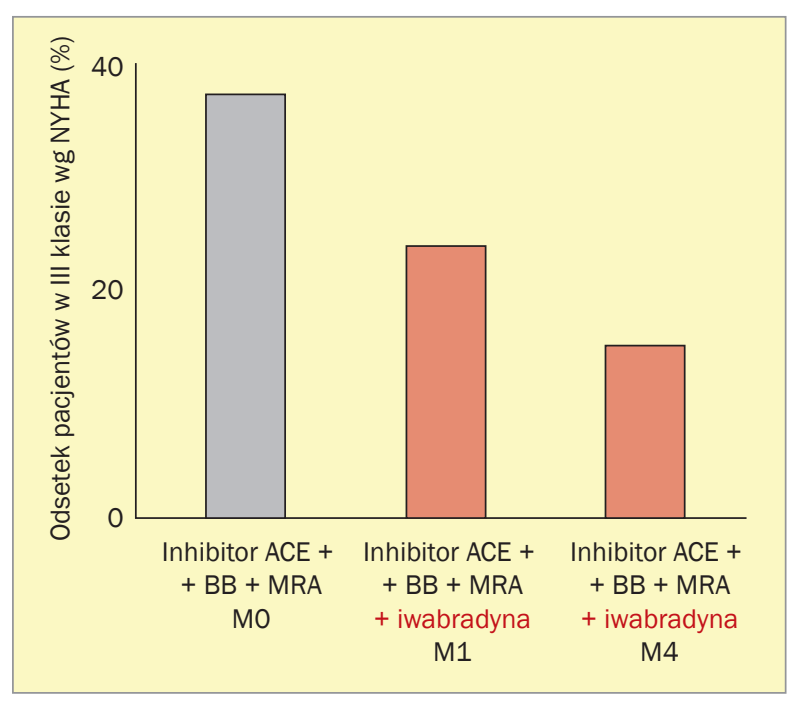

Rycina 3. Odsetek pacjentów z niewydolnością w III klasie według New York Heart Association (NYHA) włączonych do rejestru INTENSIFY - wyjściowo (M0), 1 (M1) i 4 (M4) miesiące po dołączeniu iwabradyny do dotychczasowego leczenia (opracowano na podstawie [25]); ACE (angiotensin-converting enzyme) - enzym konwertazy angiotensyny; BB ( $\beta$-blockers) - $\beta$-adrenolityki; MRA (mineral corticoid receptor antagonists) - antagoniści receptorów mineralokortykoidowych

daily effectiveNess and TolEraNce of ivabradine in chronic Systollc heart Failure in GermanY) dotyczącym 1956 pacjentów z niewydolnością serca leczonych ambulatoryjnie wykazano, że dołączenie iwabradyny do dotychczasowego schematu terapii zmniejsza uciążliwe objawy, poprawia klasę według NYHA oraz wpływa korzystnie na jakość życia pacjentów, redukując objawy ograniczające codzienne funkcjonowanie i aktywność zawodową (ryc. 3). 


\section{Podsumowanie}

Profil pacjenta z niewydolnością serca istotnie się zmienił w ostatnich latach. Współcześni pacjenci mają nie tylko inną charakterystykę kliniczną, ale także inne potrzeby niż leczeni jeszcze kilka lat temu. Obecnie potrzebne są leki, które nie tylko obniżają ryzyko zgonu pacjentów z niewydolnością serca, ale także wpływają korzystnie na ryzyko powtórnych hospitalizacji, normalizują parametry hemodynamiczne i poprawiają tolerancję wysiłku. Takim lekiem okazała się iwabradyna, która nie tylko istotnie zmniejsza częstość rytmu serca, ale także korzystnie wpływa na wszystkie wymienione wyżej parametry, stanowiąc jednocześnie najnowocześniejszą formę leczenia dla pacjentów z niewydolnością serca.

\section{Abstract}

Ivabradine is a unique, modern drug which mechanism of action is blocking the $\mathrm{I}_{f}$ current in the sinoatrial node. This translates into a reduction in heart rate - a parameter associated with poor prognosis in patients with heart failure. Today, the group of heart failure patients is different from the one we encountered in clinical practice a few years ago. Due to the different demographic structure and different health needs, methods of medical treatment must also be subject to continuous modifications. Ivabradine is a drug responding to the needs of a modern heart failure patient, providing not only a reduction in mortality, but also improvement in other factors such as the risk of re-hospitalization hemodynamic parameters, exercise tolerance and quality of life.

Key words: ivabradine, heart failure, heart rate

Folia Cardiologica 2015; 10, 5: 348-353

\section{Piśmiennictwo}

1. Heidenreich P.A., Trogdon J.G., Khavjou O.A. i wsp. Forecasting the future of cardiovascular disease in the United States: a policy statement from the American Heart Association. Circulation 2011; 123 : 933-944.

2. Stewart S., Jenkins A., Buchan S. i wsp. The current cost of heart failure to the National Health Service in the UK. Eur. J. Heart Fail. 2002; 4: 361-371.

3. Mosterd A., Hoes A.W. Clinical epidemiology of heart failure. Heart 2007; 93: 1137-1146.

4. Laribi S., Aouba A., Nikolaou M. i wsp.; GREAT network. Trends in death attributed to heart failure over the past two decades in Europe. Eur. J. Heart Fail. 2012; 14: 234-239.

5. Rywik T.M., Kozierski J., Piotrowski W. i wsp. Trends in heart failure mortality in Poland between 1980 and 2010. Pol. Arch. Med. Wewn. 2013; 123: 664-671.

6. Shafazand M., Schaufelberger M., Lappas G. i wsp. Survival trends in men and women with heart failure of ischaemic and non-ischaemic origin: data for the period 1987-2003 from the Swedish Hospital Discharge Registry. Eur. Heart J. 2009; 30: 671-678.

7. Goldacre M.J., Mant D., Duncan M., Griffith M. Mortality from heart failure in an English population, 1979-2003: study of death certification. J. Epidemiol. Commun. Health 2005; 59: 782-784.

8. Jhund P.S., Macintyre K., Simpson C.R. i wsp. Long-term trends in first hospitalization for heart failure and subsequent survival between 1986 and 2003: a population study of 5.1 million people. Circulation 2009; 119: 515-523.

9. Davídkovová H., Kysely J., Kríz B. i wsp. Trends in cardiovascular mortality and hospitalisations, and potential contribution of inhospital case-fatality rates to changes in national mortality in the Czech Republic 1994-2009. Heart 2013; 99: 409-416.
10. Greene S.J., Vaduganathan M., Wilcox J.E. i wsp.; EVEREST Trial Investigators. The prognostic significance of heart rate in patients hospitalized for heart failure with reduced ejection fraction in sinus rhythm: insights from the EVEREST (Efficacy of Vasopressin Antagonism in Heart Failure: Outcome Study With Tolvaptan) trial. JACC Heart Fail. 2013; 1: 488-496.

11. Habal M.V., Liu P.P., Austin P.C. i wsp. Association of heart rate at hospital discharge with mortality and hospitalizations in patients with heart failure. Circ. Heart Fail. 2014; 7: 12-20.

12. Berdeaux A. Preclinical results with $I_{f}$ current inhibition by ivabradine. Drugs 2007; 67 (supl. 2): 25-33.

13. Swedberg K., Komajda M., Böhm M. i wsp.; SHIFT Investigators. Ivabradine and outcomes in chronic heart failure (SHIFT): a randomised placebo-controlled study. Lancet 2010; 376: 875-885.

14. Böhm M., Borer J., Ford I. i wsp. Heart rate at baseline influences the effect of ivabradine on cardiovascular outcomes in chronic heart failure: analysis from the SHIFT study. Clin. Res. Cardiol. 2013; 102: 11-22.

15. Ambrosy A.P., Fonarow G.C., Butler J. i wsp. The global health and economic burden of hospitalizations for heart failure: lessons learned from hospitalized heart failure registries. J. Am. Coll. Cardiol. 2014; 63: 1123-1133.

16. Solomon S.D., Dobson J., Pocock S. i wsp.; Candesartan in Heart failure: Assessment of Reduction in Mortality and morbidity (CHARM) Investigators. Influence of nonfatal hospitalization for heart failure on subsequent mortality in patients with chronic heart failure. Circulation 2007; 116: 1482-1487.

17. Borer J.S., Böhm M., Ford I. i wsp.; SHIFT Investigators. Effect of ivabradine on recurrent hospitalization for worsening heart failure in patients with chronic systolic heart failure: the SHIFT Study. Eur. Heart J. 2012; 33: 2813-2820. 
18. Mulder P., Barbier S., Chagraoui A. i wsp. Long-term heart rate reduction induced by the selective I(f) current inhibitor ivabradine improves left ventricular function and intrinsic myocardial structure in congestive heart failure. Circulation 2004; 109: 1674-1679.

19. De Ferrari G.M., Mazzuero A., Agnesina L. i wsp. Favourable effects of heart rate reduction with intravenous administration of ivabradine in patients with advanced heart failure. Eur. J. Heart Fail. 2008; 10 : 550-555.

20. Reil J.C., Tardif J.C., Ford I. i wsp. Selective heart rate reduction with ivabradine unloads the left ventricle in heart failure patients. J. Am. Coll. Cardiol. 2013; 62: 1977-1985.

21. Volterrani M., Cice G., Caminiti G. i wsp. Effect of Carvedilol, Ivabradine or their combination on exercise capacity in patients with Heart Failure (the CARVIVA HF trial). Int. J. Cardiol. 2011; 151: 218-124.
22. Sarullo F.M., Fazio G., Puccio D. i wsp. Impact of "off-labe" use of ivabradine on exercise capacity, gas exchange, functional class, quality of life, and neurohormonal modulation in patients with ischemic chronic heart failure. J. Cardiovasc. Pharmacol. Ther. 2010; 15: 349-355.

23. Sosnowska-Pasiarska B., Bartkowiak R., Wożakowska-Kapłon B. i wsp. Population of Polish patients participating in the Heart Failure Pilot Survey (ESC-HF Pilot). Kardiol. Pol. 2013; 71: 234-240.

24. Siennicka A.E., Gościńska-Bis K., Wilczek J. i wsp. Perception of health control and self-efficacy in heart failure. Kardiol. Pol. 2015 Jul 23. doi: 10.5603/KP.a2015.0137.

25. Zugck C., Martinka P., Stöckl G. Ivabradine treatment in a chronic heart failure patient cohort: symptom reduction and improvement in quality of life in clinical practice. Adv. Ther. 2014; 31: 961-974. 